\title{
Dubravka Sesar
}

\section{MODALNI MODELI U HRVATSKOM I DRUGIM SLAVENSKIM JEZICIMA ${ }^{1}$}

\section{Uvod}

Dolazeći od razlika u teorijskom pristupu sintaktičkoj obradi hrvatskoga i većine slaven1 skih jezika, ovdje ćemo se baviti modalnom sastavnicom pojedinih tipova jednostavnih iskaza, odnosno rečenica različitoga sadržaja. Usporedbom hrvatskih modalnih obrazaca s češkima, poljskima i ruskima, pokušat ćemo redefinirati osnovne modalne modele u hrvatskom jeziku.

U hrvatskim normativnim sintaksama pojam modalnosti i dalje ostaje slabo razjašnjen, naime, u postojećoj obradi prevladavaju dva različita pristupa, od kojih je onaj tradicionalni (Težak i Babić 1996: 195-196, 236, 275) zastario, dok se drugi, svojedobno vrlo moderan, zasniva na transformacijsko-generativnom postupku preoblika (Barić et al. 1995: 444-454; Katičić 1986: 17, 21, 32 i d.), odnosno izvođenja različitih modalnih od "amodalnih" struktura. Naglašavajući logičko-psihološke odrednice rečenice, tj. njezin "sadržaj", "značenje" ili "smisao", tradicionalni pristup zapostavlja strukturna, gramatičko-leksička i intonacijska razlikovna obilježja osnovnih modalnih obrazaca, a transformacijsko-generativni model izvodeći različite preoblike iz temeljnih struktura (npr. upitne ili niječne iz ne-upitnih i neniječnih), a ne obratno, sugerira "amodalnost" tih temeljnih struktura, redovito indikativnih i afirmativnih. Čini se da je u obradi hrvatske sintakse, za razliku od sintaksa drugih slavenskih jezika, izostala ona razvojna faza koja tradicionalni deskriptivni pristup povezuje s transformacijsko-generativnim i koja je hrvatskoj gramatičarskoj tradiciji najprimjerenija. Riječ je o obradi sintakse - u svoj njezinoj složenosti, sa svim njezinim sastavnicama (uključujući i modalnu) - na klasičnom strukturno-funkcionalnom načelu. ${ }^{2}$ I u semantičkom pristupu sintaksi, koji je inače karakterističan za suvremeno poljsko jezikoslovlje, također se operira strukturno-funkcionalnim pokazateljima, koji su, uostalom, neizbježan instrumentarij gramatičkoga opisa.

U hrvatskoj normativnoj literaturi modalnost eksplicitno obrađuje samo Pranjkovićeva srednjoškolska sintaksa (1995: 14-16), međutim, i u njoj, prema tradicionalnom pristupu, modalnost uključuje i emocionalnost (usklične rečenice), što u sintaksama većine slavenskih jezika nije slučaj (iznimka su, donekle, ruske sintakse). Emocionalnost se u njima tretira kao izvanjezična (psihološka) kategorija koja se može izraziti svim jezičnim sredstvima, pa i modalnim, ali tada su ta sredstva emocionalno obilježena. Kako se emocionalnost kazivača, odnosno njegova iskaza, ne može odrediti samo pomoću semantičkih kriterija, jezični sustav ostaje jedina objektivna i neutralna osnova relevantna za utvrđivanje emocionalne,

\footnotetext{
Tekst je dotjerana verzija članka koji je objavljen u Suvremenoj lingvistici br. 51-52 (2001).
}

2 Međunarodni znanstveni skup o pitanjima slavenske sintakse, održan u Brnu 1971. godine, u cijelosti je bio posvećen modalnosti u slavenskim jezicima; veliki istoimeni zbornik (Otázky slovanské syntaxe III) ne donosi ni jedan kroatistički prilog. 
stilske i dr. obilježenosti određenoga iskaza u okviru postojećega ili pretpostavljenoga konteksta.

\section{Teorijska tumačenja modalnosti}

Osnovni je problem u definiranju modalnosti sličan onome u definiranju rečenice. I ta se definicija uvijek kreće na granici jezičnoga (sintaktičkoga) i logičko-semantičkoga poimanja problema. Ovisno o gramatičkoj tradiciji, razini obrade sintakse i teorijskom pristupu sintaksi određenoga jezika, i u znanstvenoj i u normativnoj literaturi nalazimo velik broj definicija modalnosti. Modalnost u širem smislu općenito se definira kao trostruk odnos - između kazivača (njegove intencije), sadržaja iskaza (iskaz kao jedinica govora na jezičnom planu odgovara rečenici) i zbilje (obuhvaćene sadržajem iskaza). U tumačenju modalnosti načelno se razlikuju dva polazišta: jedno je pozicija (nakana, intencija) kazivača, tj. njegov mogući odnos prema zbilji, a drugo je način iskazivanja određenoga sadržaja, koji se očituje u načinu oblikovanja iskaza. Iz teorijskih razmatranja proizlazi da kriterij kazivačeve nakane naglašava moguću višeznačnost sadržaja njegova iskaza i smješta pitanje modalnosti na semantički plan, dok način iskazivanja određenoga sadržaja i oblikovanja iskaza prenosi modalnost na sintaktičku razinu. Modalnost se u najširem smislu (i ne samo u sintaksama slavenskih jezika) definira kao sintaktičko-semantička kategorija s određenim formalnim (strukturnim) razlikovnim obilježjima, karakterističnim za pojedine jezike. Ta su razlikovna obilježja ujedno kriteriji za utvrđivanje polifunkcionalnosti, a time i moguće višeznačnosti pojedinih oblika i struktura (npr. uzlazna se intonacija, kao razlikovno obilježje tzv. totalnih upitnih iskaza, u funkciji retoričkoga pitanja mijenja u silaznu).

Usporedbom sintaksa slavenskih jezika uočava se nekoliko elemenata zajedničkih svim definicijama modalnosti, bez obzira na razlike u teorijskom pristupu, iz kojih onda proizlaze i terminološke razlike.

a) Modalnost je uvijek obrađena na razini iskaza, a iskaz se definira kao konkretna, procesualna jedinica govora, bitno određena sadržajem, koja se na normativnoj razini može identificirati s rečenicom. ${ }^{3}$ Ustroj iskaza najjednostavnije definiraju Bauer i Grepl (1970: 10-12), koji navode četiri njegove sastavnice: leksičku, modalnu, gramatičku i kontekstualnu (obavijesnu).

b) Drugo načelo zajedničko novijim sintaksama slavenskih jezika je razdvajanje modalnosti i emocionalnosti kao dviju kategorijski različitih razina govora. Usklične se rečenice definiraju kao emocionalno obilježeni (kontekstualizirani ili situacijski aktualizirani) modalni modeli, ${ }^{4}$ a pojedina modalna sredstva (kao i druga jezična sredstva) mogu funkcionirati kao indikatori emocionalnosti. ${ }^{5}$

3 Činjenica da modalnost pripada domeni iskaza, a ne rečenice, "nikako ne znači da i sredstva izražavanja opće modalnosti imaju iskazni (govorni), tj. nejezični, nesustavni karakter. Konkretni glagolski načini i vrste završnih intonacija bez dvojbe pripadaju jeziku (langue), i to ne samo pojedina sredstva, nego i njihove ustaljene kombinacije, osnovne modalne sheme" (Grepl 1973: 28-29). I one su, naime, konvencionalizirane, društveno ovjerene i normativne.

4 Primjeri uskličnih rečenica u hrvatskim sintaksama potvrđuju da nije riječ ni o kakvim posebnim strukturama, nego o emocionalno obilježenim izjavnim, upitnim, zapovjednim i željnim rečenicama.

5 O tome opširnije u: Sesar 1992-1993. 
c) Treću poveznicu čini podjela na tri načelno različita tipa opće modalnosti ili modalnosti u širem smislu (Šmilauer 1966: 21): (1) osnovnu, intencijsku modalnost obilježava kazivačeva nakana ili "ciljna usmjerenost (priopćajna svrha)" njegova izjavnoga, upitnoga, zapovjednoga ili željnoga iskaza. Ta je modalnost kao konstitutivna sastavnica svakoga iskaza relevantna za ostvarivanje predikacije. ${ }^{7}$ Ona uključuje druga dva tipa modalnosti, koji su sintaktički fakultativni: (2) modalnost vjerodostojnosti ${ }^{8}$ obilježava stupanj sigurnosti ili nesigurnosti kazivača $u$ istinitost, vjerodostojnost određene situacije, a (3) voluntativna modalnost izražava različite semantičke nijanse nužnosti, mogućnosti i namjere, odnosno kazivačevo mišljenje o uvjetima ostvarivosti neke situacije. Bez obzira na razlike u teorijskom pristupu, a shodno tome i poimanju modalne funkcije pojedinih jezičnih sredstava (primjerice u okviru modalnosti vjerodostojnosti), i novije semantičke sintakse slavenskih jezika na isti način definiraju i razvrstavaju osnovne modalne tipove. ${ }^{9}$ Takva strukturno-funkcionalna podjela u svakom slučaju prethodi semantičkoj tipologizaciji modalnosti, s kojom u sintaktičkoj analizi korespondira. ${ }^{10}$

U kontekstu navedene podjele postavlja se i pitanje objektivnosti i/ili subjektivnosti modalnosti. Različiti jezikoslovci i o tome sude različito, ovisno o već spomenutim osnovnim pristupima modalnosti, o određivanju nositelja modalnosti i izboru jezičnih sredstava u oblikovanju iskaza. Kako su mišljenja u znanstvenim radovima podijeljena - od onoga da su u svakom tipu modalnosti zastupljeni i objektivni i subjektivni elementi do takvoga da se subjektivna modalnost izražava leksičkim, a objektivna gramatičkim sredstvima, ${ }^{11}$ iz usporedbe s rješenjima u normativnoj literaturi proizlazi da je jedino iskaz, odnosno rečenica kao jezična kategorija, objektivan pokazatelj opće modalnosti, a time i osnovno mjerilo stupnja subjektivnosti kazivača ili nekog drugog modalizatora.

Semantičko se određenje objektivnosti ili subjektivnosti iskaza, uvijek povezano s komunikacijsko-pragmatičkim (obavijesnim), u svakom slučaju oslanja na njegov jezični (gramatički) ustroj, ili drugim riječima - značenje iskaza utvrđuje se s obzirom na odnos između njegove tematske i rematske sastavnice, koji se, uz ostalo, očituje redom riječi i konvencionalnim izborom modalnih sredstava u pojedinim tipovima iskaza. Npr. iskaz Petar bi to

$6 \quad$ Pranjković 1995: 16; sličnim se terminom koriste ruske sintakse, npr. Valgina 1978: 74-78.

7 O odnosu predikacije i modalnosti u slavističkoj se znanstvenoj literaturi susreću različita razmišljanja u smislu mogućega postojanja modalnosti izvan predikacije i predikacije bez modalnosti; pri tome se i pojam predikacije tumači ili sa sintaktičko-funkcionalnoga ili s primarno semantičkoga aspekta.

8 Termin je iskonstruiran prema češkoj imenici jistota (sigurnost) i ruskoj уверенность (uvjerenost, sigurnost), koje atribuiraju ovu modalnost; u hrvatskom se za potrebe normativne uporabe vjerojatno može naći bolji naziv. Ovaj dio sintakse i inače karakterizira velika terminološka raznolikost koja je dijelom posljedica kombiniranja različitih kriterija u pristupu modalnosti.

9 Razvrstavajući iskaze "s obzirom na odnos kazivača prema sadržaju iskaza" i najnovije poljske sintakse (npr. Labocha 1995, Strutyński 1997) navode spomenute osnovne modalne tipove. U češkim se sintaksama - Bauera i Grepla (1970), Grepla i Karlíka (1986) i Přiručni mluvnice češtiny, (1995) najzornije očituje postupni prijelaz od strukturno-funkcionalnoga do komunikacijsko-pragmatičkoga i semantičkoga teorijskoga pristupa sintaktičkoj problematici.

10 Takav je primjer monografija D. Rytel (1982) koja Lyonsovu semantičku tipologiju modalnosti (epistemičku, deontičku i aletičku modalnost) primjenjuje na češki i poljski jezik.

11 Prilozi u zborniku Otázky slovanské syntaxe III (1973) donose niz različitih mišljenja o tome pitanju. 
učinio drugačije semantički se može raščlaniti ovako: 1) Petar to objektivno pod određenim uvjetima može ili zna učiniti drugačije, ${ }^{12}$ 2) na osnovi objektivnih pokazatelja kazivač subjektivno pretpostavlja da to Petar pod određenim uvjetima može ili zna učiniti drugačije, ${ }^{13}$ 3 ) istu subjektivnu pretpostavku iskazuje neki drugi modalizator. ${ }^{14}$ Kontekst određuje čime je "realno" uvjetovano da to Petar učini drugačije i je li bitno da bi on to učinio drugačije od npr. Ivana ili da bi to učinio drugačije kad bi mogao, morao ili htio (kad je uvjet kontekstom određen, kondicionalni se iskaz može preoblikovati u indikativni, npr. Ako se potrudi, Petar to može učiniti drugačije od Ivana.). Potencijalnost iskaza, izražena kondicionalom, nije dakle nužno subjektivna. Silazna intonacija i rečenični naglasak na priložnoj oznaci načina potvrđuju da je u ovoj izjavnoj rečenici rematski dio iskaza na predikatnom dodatku, odnosno da je red riječi objektivan, a raspored tematskoga i rematskoga dijela iskaza neutralan $(\mathrm{T}+\mathrm{R})$. Da je u rečenici s istim redom riječi rečenični naglasak na subjektu, intonacija bi se promijenila u uzlazno-silaznu kadencu, raspored teme i reme bio bi obrnut $(\mathrm{R}+\mathrm{T})$ i cijeli bi iskaz bio obilježen. Zbog naglašene subjektivnosti kazivača (ili nekog drugog modalizatora) takav se iskaz svrstava u usklične rečenice. Navedeni primjer bar donekle pokazuje da su modalne sastavnice iskaza (rečenice) - glagolski način i vrsta završne (konkluzivne) intonacije - polazišta relevantna za daljnju, kontekstualnu i semantičku analizu.

\section{Vrste modalnosti}

Usporedbom istovrsnih modalnih modela (iskaza ili rečenica razvrstanih "prema sadržaju") u slavenskim jezicima pokušat ćemo odrediti razlikovna obilježja hrvatskih modalnih obrazaca na razini osnovne, intencijske modalnosti, uključujući i modalnost vjerodostojnosti i voluntativnu modalnost. Budući da je modalnost svojstvo svake rečenice, pri usporedbi ćemo se poslužiti iskazima koji su u sintagmatsko-predikacijskom smislu rečenice (jasno je da u komunikacijsko-pragmatičkom smislu svaki iskaz nije i ne mora biti rečenica).

(1) Tako se osnovna, intencijska modalnost, kojom kazivač prilikom govorne realizacije oblikuje svoj iskaz kao izjavnu, upitnu ili zahtjevnu (zapovjednu ili željnu) rečenicu, iskazuje pomoću osnovnih, konstitutivnih modalnih sredstava - glagolskoga načina i određenoga tipa završne intonacije.

(2) Modalnost vjerodostojnosti, kojom, kao što smo spomenuli, kazivač iskazuje stupanj svoje sigurnosti ili nesigurnosti u istinitost, vjerodostojnost određene situacije, podrazumijeva jestno ili niječno oblikovanje izjavnih i upitnih rečenica (iskaza) pomoću modalnih riječi - čestica ili partikula (uklučujući i načinske priloge) i modalnih glagola koji su obično u kondicionalu.

(3) Voluntativna modalnost, kojom kazivač iskazuje svoje mišljenje o uvjetima ostvarivosti neke situacije, odnosno o nužnosti, mogućnosti ili namjeri (želji) da se ona ostvari,

\footnotetext{
12 Ovakav tip objektivne modalnosti poljski sintaktičari (npr. D. Rytel 1982) prema Lyonsu nazivaju aletičkom.

13 Ovdje je prema istim izvorima riječ o tzv. epistemičkoj modalnosti.

14 Prema istim izvorima - riječ je o deontičkoj modalnosti.
} 
podrazumijeva oblikovanje izjavnih, upitnih i željnih ${ }^{15}$ rečenica (iskaza) pomoću modalnih glagola ili istoznačnih modalnih predikativa. ${ }^{16}$

Navedena modalna sredstva pomoću kojih se oblikuju tipovi modalnosti (2) i (3) fakultativna su s gledišta osnovne, intencijske modalnosti (1).

U okviru navedenoga sustava, u kojemu su moguće različite kombinacije modalnih sredstava (npr. za afirmativno iskazivanje nužnosti ili niječno iskazivanje mogućnosti u izjavnim ili upitnim iskazima), valja uzeti u obzir niz semantičkih čimbenika, prije svega odrediti poziciju kazivača ili nekoga drugoga modalizatora, odnosno identificirati njegov odnos prema agensu s jedne i nositelju modalnosti s druge strane. Tu se pokazuje da sintaktička struktura i izbor modalnih sredstava ovisi o semantičkim odnosima (npr. glagoli željeti i namjeravati u iskazima namjere imaju različite funkcije, ovisno o tome je li agens nositelj modalnosti ili nije). Budući da bismo za takvu, kompleksniju usporedbu ovdje morali imati daleko više prostora, ograničit ćemo se na oblikovanje modalnih modela s obzirom na njihova jezična razlikovna obilježja.

\section{Osnovna tipologija modalnosti}

Opći, intencijski modalni model koji vrijedi za sve tipove rečenica (iskaza) može se prikazati formulom:

\section{0. intencijska modalnost $=($ partikula $)+$ glagolski način + tip završne intonacije}

Sam glagolski način obuhvaća i fakultativna modalna sredstva - modalne glagole i predikative. Budući da su partikule po definiciji modalne riječi koje, prelazeći granice među vrstama riječi, funkcioniraju kao sintagmatski neovisni dijelovi rečenice, pitanje njihove modalne konstitutivnosti u slavenskim jezicima svodi se na oblikovanje niječnih te nekih tipova zapovjednih i željnih iskaza. ${ }^{17}$ Završna (konkluzivna) se intonacija kvalificira kao jedan od fonoloških razlikovnih čimbenika. ${ }^{18}$ Tri osnovna tipa - konkluzivna kadenca, antikadenca i polukadenca - uključuju i promjenjive, varijantne intonacijske linije, ovisne o mjestu rečeničnoga naglaska (tako je silazna kadenca kod detaljnih pitanja varijanta uzlazno-silazne konkluzivne kadence). Zbog ovisnosti rečenične intonacije o prozodijskim značajkama pojedinih slavenskih jezika postoje razlike u melodiji istovrsnih iskaza, ali ne i bitne razlike među modalnim modelima tih jezika. Na isti se način, ovisno o strukturnim značajkama pojedinih slavenskih jezika, njihovi modalni modeli razlikuju gramatički

15 U zapovjednim se iskazima volja iskazuje izravno - imperativom, a modalni glagoli ne tvore imperativ.

16 Termin modalni predikativ (opširnije u: Sesar 1994) odnosi se prije svega na pridjevski dio imenskoga predikata, koji se može zamijeniti značenjski bliskim modalnim glagolom (npr. biti prisiljen = morati). U bezličnim, pasivnim konstrukcijama ovi se pridjevi pojavljuju u srednjem rodu i funkcioniraju kao istovrsni načinski prilozi. Ruski je slučaj u ovome kontekstu specifičan - u njemu se kao modalni predikativi u besubjektnim rečenicama obično pojavljuju tzv. predikativni prilozi (надо, нужно itd.).

17 Uspoređujući takve iskaze $u$ hrvatskom i nekim drugim slavenskim jezicima, pokušala sam na ovo pitanje odgovoriti u: Sesar 1996a i 1996b.

18 Bauer i Grepl (1970: 19) - prema Mathesiusu, koji ovu funkciju intonacije naziva "primarno modalnosnom". 
(morfosintaktički). Budući da se ovdje u prvom redu bavimo modalnom, a ne gramatičkom sastavnicom iskaza (rečenice), navedeni osnovni model primijenit ćemo na pojedine vrste rečenica ili tipove iskaza. ${ }^{19}$ Pri tome ćemo samo upozoriti na osnovne gramatičke razlike među njima.

\section{1. izjavna rečenica $=$ indikativ $/(\text { kondicional })^{20}+$ silazna konkluzivna kadenca}

Č. Petr to udělal jinak. P. Piotr to zrobił inaczej. R. Пётр это сделал по-другому. H. Petar je to učinio drugačije.

Č. Petr to neudělal jinak. P. Piotr tego nie zrobił inaczej. R. Пётр это не сделал по-другому. H. Petar to nije učinio drugačije.

Č. Petr to určitě/ pravděpodobně/ asi/ možná... udělal jinak. P. Piotr to pewnie/ prawdopodobnie/ chyba/ może... zrobił inaczej. R. Пётр наверное/ вероятно/ может быть... сделал это по-другому. Н. Petar je to sigurno/ vjerojatno/ valjda/ možda... učinio drugačije.

Č. Petr to musel/ měl/ mohl/ směl/ chtěl... udělat jinak. P. Piotr to miał/ musiał/ mógł/ chciał... zrobić inaczej. R. Пётр смог/ (за)хотел это сделать по-другому. H. Petar je to mo$\mathrm{rao} / \mathrm{trebao} / \mathrm{mogao} / \mathrm{smio} / \mathrm{htio} /$ želio... učiniti drugačije.

Č. Petr to nemusel/ neměl/ nemohl/ nesměl/ nechtěl... udělat jinak. P. Piotr tego nie miał/ nie musiał/ nie mógł/ nie chciał... zrobić inaczej. R. Пётр это не смог /не (за)хотел сделать подругому. Н. Petar to nije morao/ nije trebao/ nije mogao/ nije smio/ nije htio... učiniti drugačije.

Č. Petr byl povinen/ s to/ v stavu... to udělat jinak. P. Piotr powinien był to zrobić inaczej. Piotr to był w stanie zrobić inaczej. R. Пётр должен/ обязан/ способен/ в состоянии... был это сделать по-другому. Петру надо/ нужно/ можно... было это сделать по-другому. Н. Petar je to bio dužan/ u stanju... učiniti drugačije.

Č. Petr nebyl povinen/ s to/ v stavu... to udělat jinak. P. Piotr nie powinien był tego/ to zrobić inaczej. Piotr nie był w stanie tego zrobić inaczej. R. Пётр не должен/ не обязан/ не способен... был это сделать по-другому. Пётр не был в состоянии это сделать по-другому. Петру не надо/ не нужно/ нельзя... было этого (с)делать по- другому.* H. Petar to nije bio dužan/ nije bio u stanju... učiniti drugačije.

Č. Petr by to udělal jinak. P. Piotr by to zrobił inaczej. R. Пётр бы это сделал по-другому. H. Petar bi to učinio drugačije.

Č. Petr by to neudělal jinak. P. Piotr by tego nie zrobił inaczej. R. Пётр не сделал бы это по-другому. H. Petar to ne bi učinio drugačije.

Č. Petr by to určitě/ pravděpodobně/ snad/ asi/ možná... udělal jinak. P. Piotr by to pewnie/ prawdopodobnie/ chyba/ może... zrobił inaczej. R. Пётр, наверное /вероятно/ скорее всего/ может быть..., сделал бы это по-другому. Н. Petar bi to sigurno/ vjerojatno/ valjda/ možda... učinio drugačije.

Č. Petr by to musel/ měl/ mohl/ směl/ chtěl... udělat jinak. P. Piotr by to miał/ musiał/ mógł/ chciał... zrobić inaczej. R. Пётр бы мог/ хотел это сделать по-другому. H. Petar bi to morao/ trebao/ mogao/ smio/ htio/ želio... učiniti drugačije.

19 Naši su primjeri oblikovani prema primjerima iz sintaksa uspoređenih jezika, ujednačeni (radi lakše usporedbe) i provjereni kod izvornih govornika.

20 U zagradama navodimo fakultativna modalna sredstva. 
Č. Petr by to nemusel/ neměl/ nemohl/ nesměl/ nechtěl... udělat jinak. P. Piotr by tego nie miał/ nie musiał/ nie mógł/ nie chciał... zrobić inaczej. R. Пётр не (с)мог/ не хотел бы сделать это по-другому. Н. Petar to ne bi morao/ ne bi trebao/ ne bi mogao/ ne bi smio... učiniti drugačije.

Č. Petr by byl povinen/ s to/ v stavu... to udělat jinak. P. Piotr byłby to powinien/ w stanie... zrobić inaczej. R. Пётр должен/ способен/ в состоянии... был бы сделать это подругому. Петру надо/ нужно... было бы это сделать по-другому. Петру (бы) сделать это по другому.* H. Petar bi to bio dužan/ u stanju... učiniti drugačije.

Č. Petr by nebyl povinen/ s to/ v stavu... to udělat jinak. P. Piotr nie powinien byłby tego zrobić inaczej. Piotr nie byłby w stanie zrobić tego inaczej. R. Пётр не должен был бы этого делать по-другому. Пётр был бы не способен это сделать по-другому. Пётр не был бы в состоянии это сделать по-другому. Петру не надо/ не нужно/ нельзя... было бы это сделать по-другому* Петру не следовало бы этого делать по-другому.* H. Petar to ne bi bio dužan/ ne bi bio u stanju... učiniti drugačije.

Navedeni češki, poljski, ruski i hrvatski primjeri pokazuju da ovi jezici tvore izjavne iskaze prema istom modalnom modelu. ${ }^{21}$ Kondicional u svima vrši dvostruku funkciju: njime se iskazuje potencijalna radnja na razini intencijske modalnosti (kad su kontekstom određeni uvjeti ostvarenja radnje) ili služi kao sredstvo za iskazivanje modalnosti vjerodostojnosti (npr. Siguran sam/vjerujem/ mislim/nisam siguran da bi to Petar morao/trebao/ mogao učiniti drugačije). Za razliku od češkoga, poljskoga i hrvatskoga ruski kondicional ne poznaje kategoriju vremena pa, ovisno o kontekstu i izboru modalnoga predikativa, kopulativni pomoćni glagol (бblmb) uz kondicionalnu partikulu $\sigma b l^{22}$ može značiti irealnu ili realnu mogućnost.

Ruski se od navedenih jezika strukturno znatnije razlikuje u iskazivanju voluntativne modalnosti. Kako je u njemu funkcija modalnih glagola ograničena, ${ }^{23}$ u njihovu se značenju rabe predikativni načinski prilozi надо, нужно, можно, нельзя... (ti su primjeri označeni zvjezdicom - *), koji se u iskazima nužnosti u govoru obično izostavljaju. Pri tome cijeli iskaz postaje deagentan i preoblikuje se u besubjektnu rečenicu u kojoj je gramatički objekt u dativu uvijek živo biće (tzv. logički subjekt). ${ }^{24}$ Budući da formalno tvore poseban obrazac, ove bi se deagentne strukture gramatički mogle izdvojiti kao poseban

$\overline{21}$ Ovdje nije riječ o morfološkim razlikama koje se u našim primjerima očituju tvorbom glagolskoga vremena i načina (a time i položajem klitika i redom riječi) te oblikovanjem agentnih i deagentnih (dvočlanih i jednočlanih) rečenica s različitim modalnim predikativima.

22 Slavenski jezici koji nemaju jednostavnih prošlih vremena i "ne prepoznaju" ostatak aorista u kondicionalnoj konstrukciji obično oblik by tretiraju kao partikulu.

23 Neki slavenski modalni glagoli u ruskom ni nemaju glagolskoga ekvivalenta (npr. morati se najčešće iskazuje predikativom былть должен), a uporaba ostalih često je stilski obilježena. Ni njihova značenja ne odgovaraju uvijek značenjima istih glagola u navedenim slavenskim jezicima (npr. glagol сметь najčešće znači usuditi se). Osim toga, samo glagoli мочb, хотеть i сметь imaju lične (osobne) oblike: u prezentu - могу, хочу, смею; u futuru - смогу, захочу; u perfektu - смог, захотел.

24 Ovakve strukture postoje i u češkom (bylo/ bude nutno komu co), poljskom (trzeba było/ trzeba będzię komu co) i hrvatskom (Bilo mu je potrebno odmoriti se. Bilo mu je nemoguće/ Nije mu bilo moguće vratiti se na vrijeme), ali su funkcionalno ograničene i češće se oblikuju kao subjektne zavisne rečenice. 
modalni podsustav, a semantički se mogu priključiti iskazima s modalnim glagolima ${ }^{25}$ ili s istoznačnim pridjevskim predikativima.

\section{Upitna rečenica:}

2.1. detaljno pitanje $\mathrm{e}^{26}=$ upitna riječ ${ }^{27}+$ indikativ/(kondicional) + uzlazno-silazna/ silazna konkluzivna kadenca

Č. Kdo to udělal? P. Kto to zrobił? R. Кто это сделал? Н. Tko je to učinio?

Č. Kdy/ Jak... to Petr udělal? P. Kiedy/ Jak... to Piotr zrobił? R. Когда/ Как... Пётр это сделал? Н. Kad/ Kako... je to Petar učinio?

Č. Kdo to musel/ měl/ mohl/ chtěl... udělat? P. Kto to miał /musiał/ mógł/ chciał... zrobić? R. Кто мог/ хотел это сделать? Н. Tko je to morao/ trebao/ mogao/ htio... učiniti?

Č. Kdy/ Jak... to Petr musel/ měl/ mohl... udělat? P. Kiedy/ Jak... to Piotr miał/ musiał/ mógł... zrobić? R. Когда/ Как... Пётр мог это сделать? Н. Kad/ Kako... je to Petar morao/ trebao/ mogao... učiniti?

Č. Kdo to byl povinen/ v stavu... udělat? P. Kto to był powinien/ w stanie... zrobić? R. Кто должен был это сделать? Кто был способен/ в состоянии... это сделать? Кому надо/ нужно/ можно... было это сделать?* Н. Tko je to bio dužan/ u stanju... učiniti?

Č. Kdy/ Jak... to Petr byl povinen udělat? P. Kiedy/ Jak... to Piotr powinien był zrobić? R. Когда/ Как... Пётр должен был это сделать? Когда/ Как... Петру надо/ нужно/ можно было это сделать?* Н. Kad/ Kako... je to Petar bio dužan učiniti?

Č. Kdo by to udělal? P. Kto by to zrobił? R. Кто бы это сделал? Н. Tko bi to učinio?

Č. Kdy/ Jak... by to Petr udělal? P. Kiedy/ Jak... by to Piotr zrobił? R. Когда/ Как... бы Пётр это сделал? Н. Kad/ Kako... bi to Petar učinio?

Č. Kdo by to musel/ měl/ mohl/ chtěl... udělat? P. Kto by to miał/ musiał/ mógł/ chciał... zrobić? R. Кто бы смог/ хотел это сделать? Н. Tko bi to morao/ trebao/ mogao/ htio... učiniti?

Č. Kdy/ Jak... by to Petr musel/ měl/ mohl... udělat? P. Kiedy/ Jak... by to Piotr miał/ musiał/ mógł... zrobić? R. Когда Пётр смог/ хотел бы это сделать? Как бы Пётр мог/ хотел это сделать? Н. Kad/ Kako... bi to Petar morao/ trebao/ mogao... učiniti?

Č. Kdo by to byl povinen/ v stavu... udělat? P. Kto by to był powinien/ w stanie... zrobić? R. Кто должен был бы это сделать? Кто был бы способен/ в состоянии... это сделать? Кому надо/ нужно/ можно... было бы это сделать?* H. Tko bi to bio dužan/ u stanju... učiniti?

Č. Kdy/ Jak... by Petr byl povinen to udělat? P. Kiedy/ Jak... Piotr powinien byłby to zrobić? R. Когда/ Как... Пётр должен был бы это сделать? Когда/ Как... Петру надо/ можно... было бы это сделать?* Н. Kad/ Kako... bi to Petar bio dužan učiniti?

\footnotetext{
25 Zbog šire funkcije modalnih glagola to se u češkim i poljskim kontrastivnim ruskim sintaksama obično i čini.

26 češki - doplňovací otázka, poljski - pytanie uzupełniające, ruski - развернутый вопрос

27 upitna zamjenica ili prilog
} 
U oblikovanju tzv. detaljnih pitanja (odgovor na njih je detalj koji obavijesno upotpunjuje iskaz) među slavenskim jezicima vidimo slične razlike kao kod izjavnih rečenica. Zbog ograničene funkcije modalnih glagola ruski se i ovdje strukturno znatnije razlikuje od hrvatskoga i zapadnoslavenskih jezika. Ovaj tip pitanja većinom se oblikuje afirmativno (niječno oblikovana detaljna pitanja poprimaju određena emocionalna i stilska obilježja, kakvo ima npr. retoričko pitanje). Kondicional i ovdje, kao i kod izjavnih rečenica, ima dvostruku funkciju: služi za iskazivanje intencijske modalnosti i modalnosti vjerodostojnosti. ${ }^{28}$ Silazna se intonacija, kao uobičajena varijanta, pojavljuje kad je rečenični naglasak na upitnoj riječi.

\section{2. totalno pitanje ${ }^{29}=$ indikativ/(kondicional) + uzlazna konkluzivna antikadenca}

Č. Petr to udělal jinak? P. Piotr to zrobił inaczej? R. Пётр это сделал по-другому? Н. Petar je to učinio drugačije? (= Je li to Petar učinio drugačije?)

Č. Neudělal to Petr jinak? P. Piotr nie zrobił tego inaczej? R. Пётр не сделал это подругому? Н. Petar to nije učinio drugačije? (= Zar to Petar nije učinio drugačije?)

Č. Jestlipak to Petr udělal jinak? P. Czy Piotr to zrobił inaczej? R. Сделал ли Пётр это по-другому? Разве Пётр сделал это по-другому? H. Je li/Zar je to Petar učinio drugačije?

Č. Petr to musel/ měl/ mohl udělat jinak? P. Piotr to miał/ musiał/ mógł zrobić inaczej? R. Пётр смог/ хотел сделать это по-другому? H. Petar je to morao/ trebao/ mogao... uс̌initi drugačije? (= Je li to Petar morao/ trebao/mogao... učiniti drugačije?)

Č. Neměl/ Nemohl to Petr udělat jinak? P. Piotr nie mógł tego zrobić inaczej? R. Пётр не смог/ не хотел сделать это по-другому? H. Petar to nije morao/ nije trebao/ nije mogao učiniti drugačije? (= Nije li to Petar morao/ trebao/ mogao učiniti drugačije?)

Č. Petr byl povinen to udělat jinak? P. Piotr powinien był to zrobić inaczej? R. Пётр должен/ обязан был это сделать по-другому? Петру надо/ нужно было это сделать по-другому?* H. Petar je to bio dužan učiniti drugačije? (= Je li to Petar bio dužan učiniti drugačije?)

C. Nebyl Petr povinen to udělat jinak? P. Piotr nie powinien był tego zrobić inaczej? R. Пётр не должен/ не обязан был сделать это/ делать этого по-другому? Петру не надо/ не нужно было сделать это/ делать этого по-другому?* H. Petar to nije bio dužan učiniti drugačije? (= Nije li to Petar bio dužan učiniti drugačije?)

Č. Neudělal by to Petr jinak? P. Piotr nie zrobiłby tego inaczej? R. Пётр не сделал бы это по-другому? H. Petar to ne bi učinio drugačije? (= Ne bi li to Petar učinio drugačije?)

Č. Jestlipak by to Petr udělal jinak? Že by to Petr udělal jinak? P. Czy Piotr zrobiłby to inaczej? R. Разве Пётр сделал бы это по-другому? H. Bi li to Petar učinio drugačije?

Č. Petr by to asi udělal jinak? Udělal by to Petr snad jinak? P. Piotr by to może zrobił inaczej? R. Пётр, может быть, сделал бы это по другому? H. Petar bi to možda učinio drugačije?

\footnotetext{
$28 \quad$ Razumije se da je indikativu perfekta u svim primjerima paralelan kondicional prošli. Budući da je to za sam opis modalnoga modela nebitno, a zakompliciralo bi opis i povećalo broj primjera, ovdje dajemo primjere s kondicionalom sadašnjim.

29 češki - zjišt’ovací otázka, poljski - pytanie stwierdzające, ruski - замкнутый вопрос
} 
Č. Petr by to musel/ měl/ mohl udělat jinak? P. Piotr by to musiał/ miał/ mógł zrobić inaczej? R. Смог бы Пётр сделать это по-другому? Н. Petar bi to morao/ trebao/ mogao... učiniti drugačije? (= Bi li to Petar morao/ trebao/ mogao... učiniti drugačije?)

Č. Neměl/ Nemohl by to Petr udělat jinak? P. Piotr nie mógłby tego zrobić inaczej? R. Не мог/ Не хотел бы Пётр сделать это по-другому? H. Petar to ne bi morao/ ne bi trebao/ ne bi mogao učiniti drugačije? (= Ne bi li to Petar morao/ trebao/ mogao učiniti drugačije?)

C. Petr by to byl povinen udělat jinak? P. Piotr powinien byłby to zrobić inaczej? R. Пётр должен был бы сделать это по-другому? Петру надо/ нужно бы сделать это подругому?* Петру (бы) сделать это по-другому?* Н. Petar bi to bio dužan učiniti drugačije? (= Bi li to Petar bio dužan učiniti drugačije?)

Č. Nebyl by to Petr povinen udělat jinak? P. Piotr nie powinien byłby tego zrobić inaczej? R. Пётр не должен был бы сделать это по-другому? Не надо/ Не нужно было бы Петру этого делать по-другому?* Петру не надо/ не нужно (бы) сделать это по другому?* H. Petar to ne bi bio dužan učiniti drugačije? (= Ne bi li to Petar bio dužan učiniti drugačije?)

Budući da se gramatički i sadržajno ne razlikuju od izjavnih iskaza (sadrže odgovor kao rematski dio iskaza, koji valja samo potvrditi ili zanijekati), za totalna je pitanja distinktivna uzlazna intonacija (suprotna onoj u izjavnim rečenicama). Kondicional i ovdje, kao i kod izjavnih rečenica, ima dvostruku funkciju. Totalna se pitanja mogu bez promjene osnovnoga značenja oblikovati i niječno (takav je način u komunikaciji diskretniji).

Među totalnim pitanjima iznimku čine disjunktivna pitanja (Bi li to bolje učinio Petar ili Ivan?), kojima je intonacija uzlazno-silazna i na koja se zbog dvostruke reme ne može dati jednostavan potvrdni ili niječni odgovor.

Uporaba upitnih partikula u totalnim je pitanjima karakterističnija za hrvatski, nego za ruski i poljski, a pogotovo za češki jezik, gdje one mogu imati emocionalno obilježje (mogu npr. izražavati čuđenje, kao npr. češka partikula copak, koja se u pravim totalnim pitanjima ne rabi). Kako je upitna partikula sama po sebi razlikovno sredstvo, ona u ovim pitanjima može utjecati na promjenu intonacije, a u hrvatskom očito i utječe. Pitanje je mogu li se, s obzirom na uporabnu normu, u hrvatskom slučaju totalna pitanja s upitnom partikulom ( $l i$, zar) i uzlazno-silaznom završnom intonacijom smatrati "uobičajenom” varijantom ili čak posebnim modalnim modelom oblikovanim prema formuli:

totalno pitanje $=$ partikula + indikativ $/($ kondicional $)+$ uzlazno-silazna konkluz. kadenca

S funkcionalnoga se gledišta detaljna i totalna pitanja semantički razlikuju ovisno o adresatu: tzv. deliberativna pitanja, upućena sebi ili drugome i sebi istodobno (takva "monološka" pitanja, najčešće izrečena u 3. licu, odražavaju nesigurnost, dvoumljenje ili neodlučnost kazivača) razlikuju se od nedeliberativnih koja se uvijek upućuju drugome (ta su "dijaloška" pitanja obično u 2. licu). ${ }^{30}$ Pojedina modalna sredstva imaju u različitim tipovima ovih pitanja različita značenja (npr. kondicional u deliberativnom i nedeliberativnom - detaljnom i totalnom pitanju), koja se preciziraju pomoću drugih modalnih sredstava - partikula, modalnih glagola i dr. ${ }^{31}$

30 Ove su termine uvele češke sintakse (Bauer i Grepl 1970 i dr.).

31 Ovo je pitanje detaljnije semantičke analize kojim se bavimo i u: Sesar 1998. 
3. Zahtjevna rečenica:

3.1. zapovjedna rečenica $=$ imperativ + silazna konkluzivna kadenca

Č. Udělej to, prosím tě. P. Zrób to, proszę cię. R. Сделай это, пожалуйста. H. Učini to, molim te.

Č. Udělej to hned! P. Zrób to natychmiast! R. Сделай это сразу! H. Učini to odmah!

Č. Nedělej to! P. Nie rób tego! R. Не делай это/этого! H. Ne čini to! Nemoj to činiti/ učiniti.

Č. Nedělej to tak narychlo. P. Nie rób tego tak szybko. R. Не делай это так быстро. H. $\mathrm{Ne}$ čini to na brzinu. Nemoj to činiti/učiniti na brzinu.

3.1.1. zapovjedna rečenica $=$ partikula + indikativ + silazna konkluzivna kadenca

Č. At’ to udělá hned! P. Niech to zrobi natychmiast! R. Пусть он это сделает сразу! Н. Neka to učini odmah!

Č. At’ to nedělá tak narychlo. P. Niech tego nie robi tak szybko. R. Пусть он не делает этого так быстро. H. Neka to ne čini na brzinu.

U gramatičkoj strukturi izravnih zapovjednih iskaza, za koje je razlikovan sam imperativ, među navedenim slavenskim jezicima nema veće razlike. Paralelna je i uporaba vida - svršenoga u afirmativno izrečenoj naredbi i nesvršenoga u zabrani. Ovdje jedino hrvatski ima i mogućnost tvorbe složenoga izravnoga imperativa u značenju zabrane - pomoću niječne partikule nemoj, nemojmo, nemojte i infinitiva punoznačnoga svršenoga i nesvršenoga glagola. Gramatičku strukturu neizravnoga imperativa (sa zapovjednim partikulama i indikativom) imaju i željni iskazi, ali im je intonacija drugačija.

3.2. željna rečenica $=$ partikula + kondicional/indikativ + uzlazno-silazna konkl. kadenca

Č. Kéž by to Petr udělal co nejdříve! Kdyby jen Petr to udělal co nejdříve! P. Oby to Piotr zrobił jak najprędzej! Gdyby to Piotr (tylko) zrobił jak najprędzej! R. Если бы/ Только бы/ Лишь бы/ Хоть бы Пётр это сделал как можно быстрее! Только бы/ Лишь бы/ Хоть бы Петру сделать это как можно быстреe! H. Kad bi to Petar bar učinio što prije!

Č. Kéž to Petr udělá co nejdříve! Jen at' to Petr udělá co nejdříve! P. Niech to Piotr (tylko) zrobi jak najprędzej! R. Пусть Пётр это сделает как можно быстреe! H. Da to Petar bar učini što prije! Samo da to Petar učini što prije! Neka to Petar (samo) učini što prije!

Za razliku od izjavnih i upitnih rečenica u kojima indikativ označava realnu, a kondicional irealnu, potencijalnu radnju, u željnim se rečenicama ova razlika neutralizira pa i indikativ i kondicional podjednako znače potencijalnost. Budući da posebne željne par-

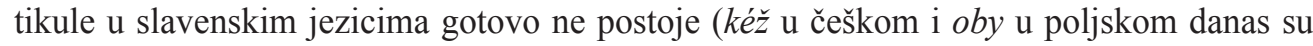
arhaične), partikule vezničkoga ili priložnoga tipa, koje se vežu s kondicionalom, rjeđe s indikativom (u hrvatskom se oba načina rabe ravnopravno), u željnim se rečenicama mogu smatrati modalno konstitutivnima. Naime, unatoč njihovoj slaboj gramatičkoj i još slabijoj leksičkoj razlikovnosti, željni su iskazi u formi zavisne rečenice prepoznatljivi upravo po tim partikulama. 
Budući da iskazi oblikovani kao zavisne rečenice ne mogu imati rečenični naglasak na vezničkim riječima i da je rematski dio takvih iskaza (u objektivnom redu riječi) odmaknut od partikule i vezan za predikat ili dio predikatnoga skupa, za njih je distinktivna uzlazno-silazna završna intonacija. Ona je objektivno distinktivna i za željne iskaze oblikovane pomoću željnih partikula, bez obzira na njihovu manje ili više izraženu emocionalnu komponentu.

Uz navedene valja spomenuti i partikule pomoću kojih se najčešće iskazuju loše želje, npr. - u češkom Bodejt' (by) tě husa kopla!, u poljskom Bodajś się udtawił!, u ruskom Чтоб ты провалился! Чтоб тебе провалиться!, koje u hrvatskome nemaju neutralnoga modalnoga ekvivalenta; semantički je najbliži takvome tipu optativni iskaz bez partikule, npr. Vrag te odnio! (za razliku od obilježenoga: Dabogda te vrag odnio!).

Vrsta željnih iskaza su i ustaljeni, konvencionalni sklopovi riječi - pozdravi, dobre želje, čestitke, zdravice, povici na javnim manifestacijama. Oblikuju se pomoću imperativa (u češkom npr. Bud' zdráv! Mějte se dobře!, u poljskom Bąź zdrów!, u ruskom Бydb здоров!, u hrvatskom Budi mi živ $i$ zdrav!) ili indikativa sa spomenutim partikulama - u češkom at' (At'se vám to podaři!'), u poljskom niech (Niech żyje!), u ruskom nycmb (Пycmb спят в покое!), да (Да здравствует солнце!), u hrvatskom neka (Neka vas prati sreća!). Ovakve se želje iskazuju i bez partikula, u ruskom npr. infinitivom (Добро пожаловать! Счастливо оставаться!), а u hrvatskom participom aktivnim (Živio! Dobro došli! Veseli i zdravi bili! $\left.{ }^{32}\right)$.

Navedeni primjeri (reducirani na one najtipičnije) potvrđuju da su željne rečenice semantički najbliže uskličnima; odatle i njihova strukturna raznolikost i intonacijska promjenjivost. Međutim, činjenica da se jedino željne rečenice tvore prema modalnom modelu s kondicionalom (kojemu je indikativ ravnopravna alternativa, posebice u hrvatskom) i partikulama vezničkoga ili priložnoga podrijetla, koje su s njim čvrsto ili labavo srasle, ${ }^{33}$ daje za pravo onim sintaktičarima koji željne rečenice definiraju kao poseban modalni tip. Takvo mišljenje podupire i činjenica da se usklične rečenice, kao emocionalna kategorija, oblikuju unutrašnjom preobrazbom svih, a ne samo željnih, modalnih modela.

Emocionalno obilježavanje modalnih modela očituje se prije svega promjenom rečenične intonacije, a to znači promjenom mjesta rečeničnoga naglaska, odnosno (neutralnoga) položaja rematskoga dijela iskaza, što je često povezano i s promjenom reda riječi. Na isti se način emocionalnost očituje i u mogućnosti zamjene funkcija glagolskih načina, odnosno u promjeni njihovih osnovnih funkcija (npr. indikativ se često rabi u funkciji imperativa ili kondicionala). Emocionalnost takvih iskaza pojačavaju fakultativna modalna i druga jezična sredstva, prije svega usklici i partikule, kao i izabrani leksik. U svim se slavenskim jezicima mogu izvesti slične preobrazbe, a njihova usporedba najbolje otkriva komunikacijsko-pragamatičke funkcije elemenata govora i složene semantičke odnose u svakom pojedinom jeziku.

\footnotetext{
32 S obzirom na svoju modalnu specifičnost ovakvi se iskazi mogu nazvati optativnima.

33 Rječnici slavenskih jezika potvrđuju da su vezničke i priložne sveze s kondicionalom u velikoj većini leksikalizirane.
} 


\section{Zaključak}

Iako su u ovom kratkom prilogu proučavanju slavenskih jezika prikazani samo osnovni modalni modeli, izložena građa pokazuje niz posebnosti hrvatske sintakse u usporedbi s češkom i poljskom s jedne te ruskom s druge strane. Već i sami modeli nameću niz pitanja o tipologiji pojedinih modalnih sredstava (npr. glagolskih načina, modalnih glagola, varijantnosti završne intonacije itd.), njihovim značenjima i funkcijama. Određena otvorena pitanja vezana uz modalnost i općenito sintaktičku problematiku potvrđuju da je jezik fenomen koji se nikakvim istraživanjima ne može iscrpiti. Komparativna jezikoslovna istraživanja imaju pritom dvostruku vrijednost - daju potpuniji uvid u svaki uspoređeni jezik i zasigurno pridonose otkrivanju skrivenih obilježja uspoređivanih jezika, čak i onih koji su temeljito opisani i optimalno normirani. Kad je riječ o hrvatskoj sintaksi, svaka usporedba sa srodnim, slavenskim jezicima, može samo pomoći da se razjasne određene dvojbe, uklone neke nepreciznosti i nađu jasni odgovori na mnoga pitanja. 